\title{
Hambatan dan Harapan Pemartabatan Bahasa Indonesia
}

\author{
Mohamad Jazeria1 dan Siti Zumrotul Maulida ${ }^{\text {a2 }}$
}

${ }^{a}$ IAIN Tulungagung

${ }^{1}$ jeryadiba2016@gmail.com, ${ }^{2}$ zumrotul.sm@gmail.com

\begin{tabular}{l} 
Article info \\
\hline Article history: \\
Received: 14-02-2018 \\
Revised : 12-09-2018 \\
Accepted: 18-12-2018
\end{tabular}

Keyword:

BIPA

foreigner

Indonesian

language

strategic

\author{
A B S T R A C T
}

This article aims to explain the phenomena of dignifying the Indonesian language between obstacles from Indonesian people and hopes from people of other countries to learn and use the Indonesian language. Based on my prolong observation, I find that people of Indonesia nowadays are lack of pride and loyalty to use The Indonesian language. On the other hand, the number of foreigners who are interested in learning the Indonesian language is highly rocketed. In our country, we face some phenomena of using The Indonesian language with lack of pride and loyalty. Language pride is the pride of Indonesian people to use Indonesian language pride, while language loyalty is the wish to use and maintain the Indonesian language from interference and extinction. The hopes from outside are the increasing number of foreigners who learn the Indonesian language for many purposes. It is proved by, first, the Indonesian language is now promoted as an official language of ASEAN countries. Second, the Indonesian language is learned in some universities in foreign countries. Third, in line with the strategic position of Indonesia in global communication, politically, economically, and culturally, the need of Indonesian Language Teaching for Foreigner (BIPA) is rapidly increasing.

Penelitian ini bertujuan untuk menjelaskan fenomena yang terjadi dalam pemartabatan bahasa Indonesia, yakni hambatan yang terjadi di dalam negeri dan harapan dari luar negeri. Hasil pengamatan menunjukkan bahwa kebanggaan dan loyalitas warga negara Indonesia terhadap bahasa Indonesia masih rendah. Di sisi lain, bangsa lain semakin banyak yang tertarik mempelajari bahasa Indonesia. Hambatan yang dihadapi di dalam negeri adalah kurangnya kebanggaan terhadap bahasa Indonesia dan rendahnya loyalitas terhadap bahasa Indonesia. Kebanggaan terhadap bahasa Indonesia adalah rasa bangga menggunakan bahasa Indonesia. Sementara loyalitas terhadap bahasa Indonesia merupakan keinginan bangsa Indonesia untuk memelihara dan mempertahankan bahasa Indonesia serta mencegahnya dari pengaruh dan interferensi dari bahasa lain. Adapun harapan dari luar negeri adalah semakin tingginya minat orang asing untuk mempelajari bahasa Indonesia dengan berbagai alasan. Hal ini dapat dilihat dari pertama, bahasa Indonesia dipromosikan sebagai bahasa resmi ASEAN. Kedua, bahasa Indonesia dipelajari di beberapa perguruan tinggi di luar negeri. Ketiga, seiring dengan posisi strategis Indonesia di percaturan dunia, secara politik, ekonomi, dan budaya, permintaan layanan Bahasa Indonesia bagi Penutur Asing (BIPA) meningkat dengan cepat.

Copyright @ 2018 Institut Agama Islam Negeri Syekh Nurjati Cirebon. All rights reserved.

\section{PENDAHULUAN}

Posisi strategis Indonesia di percaturan regional maupun internasional membuat bahasa Indonesia semakin memiliki peran penting dalam komunikasi antarbangsa. Tidak mengherankan jika Susanto dan Rofiuddin (2015) memprediksi bahwa bahasa Indonesia 



akan menjadi bahasa resmi ASEAN seiring dengan diberlakukannya Masyarakat Ekonomi ASEAN (MEA). Bahkan, Wicaksono (2016) meramalkan bahasa Indonesia memiliki peluang besar menjadi bahasa internasional karena permintaan pelayananbahasa Indonesia bagi penutur asing (BIPA), baik di dalam maupun di luar negeri semakin meningkat. Setiap tahun permintaan gutu BIPA ke luar negeri selalu meningkat, baik di negara-negara ASEAN seperti Malaysia, Thailand, Vietnam, Kamboja, Laos, Brunei Darussalam, dan Filipina, maupun di negara-negara Australia, Eropa, dan Amerika.

Peluang memartabatkan status bahasa Indonesia sebagai bahasa persatuan dan salah satu bahasa internasional harus menghadapi berbagai kendala yang justru muncul dari dalam bangsa Indonesia sendiri. Fenomena maraknya Indolish di kalangan pejabat dan selebriti, merebaknya bahasa gaul dan alay di kalangan remaja, dan bergesernya namanama bangunan, toko, pusat perbelanjaan, dan tempat usaha ke dalam bahasa asing merupakan indikator rendahnya kesetiaan dan kebanggaan terhadap bahasa Indonesia. Kini, sulit rasanya menemukan pejabat yang dapat dijadikan teladan penggunaan bahasa Indonesia yang baik dan benar. Sulit juga menemukan nama hotel, kompleks perumahan, tempat wisata, nama lembaga, atau nama perkumpulan yang masih setia menggunakan bahasa nasional. Di Malang, nama-nama bisnis kuliner di sepanjang jalan Sukarno-Hatta hampir semua berbahasa asing (Khasanah, Ismatul, Dwita Laksmita, Rosa Da Cosa Tilman, Roy Rizki). Para pengguna bahasa memang lebih bangga menggunakan bahasa asing dibanding bahasa sendiri.

Kendala lain muncul dari para pejuang BIPA, yakni rendahnya kompetensi guru BIPA dan kurang tersedianya bahan ajar BIPA yang selalu mengikuti perkembangan pembelajaran bahasa. Tidak dimungkiri bahwa BIPA begitu seksi sehingga banyak orang ingin menekuni sebagai profesinya. Untuk menjadi pengajar BIPA memang tidak disyaratkan lulusan jurusan pendidikan bahasa Indonesia sehingga semua orang bisa ikut ambil bagian dalam pembelajaran BIPA. Banyak mahasiswa asing yang ketika belajar di Indonesia tidak menekuni pendidikan bahasa, namun setelah pulang ke negaranya, karena mampu berbahasa Indonesia, diminta mengajar BIPA. Hal ini membuat tingkat penguasaan teori dan praktik pembelajaran BIPA beragam. Bahan ajar yang kurang tersedia juga ditemukan di berbagai lembaga pelayanan BIPA, baik di Indonesia maupun di luar negeri. Contoh kurangnya bahan ajar BIPA dirasakan oleh Hara Mayuko (2017), pengajar BIPA di Universitas Osaka Jepang dan Nguyen Thanh Tuan (2017), pengajar 
BIPA di University of Social Science and Humanities Vietnam. Dalam hal ini Suyitno (2007) menyarankan agar penyusunan bahan ajar BIPA didasarkan pada analisis kebutuhan pebelajar.

\section{METODE}

Penelitian ini merupakan penelitian kualitatif dengan ancangan studi kasus, yakni fenomena penggunaan bahasa Indonesia di kampus. Sumber data penelitian ini adalah dosen dan mahasiswa. Data dikumpulkan melalui angket tentang kebanggaan dan loyalitas bahasa yang dikumpulkan dari dosen dan mahasiswa. Selain itu, untuk menjawab masalah kedua, data juga dikumpulkan dengan teknik dokumentasi, yakni mengumpulkan beberapa artikel dari jurnal maupun internet yang berisi pandangan-pandangan pemerhati bahasa tentang peluang-peluang internasionalisasi bahasa Indonesia serta hambatan-hambatan yang terjadi di dalam negeri. Data yang telah terkumpul, dianalisis dengan analisis data kualitatif yang diadopsi dari Miles dan Huberman (1992), yakni analisis data secara interaktif. Analisis data ini terdiri atas (1) pengumpulan data, (2) reduksi data yang, meliputi: identifikasi data, klaifikasi data, dan kodefikasi data, (3) penyajian data, serta (4) trianggulasi dan penyimpulan.

\section{HASIL DAN PEMBAHASAN}

Berdasarkan hasil analisis data dapat diketahui bahwa tantangan pemartabatan bahasa Indonesia dari dalam negeri diantaranya adalah rendahnya loyalitas terhadap bahasa Indonesia dan rendahnya kebanggaan terhadap bahasa Indonesia. Sementara itu, harapan yang datang dari luar negeri adalah semakin meningkatnya jumlah universitas di luar negeri yang mengajarkan bahasa Indonesia dan semakin banyaknya lembaga BIPA di luar negeri. Hal ini merupakan peluang besar bagi bangsa Indonesia untuk berkarier sebagai guru bahasa Indonesia di luar negeri dan semakin besar peluang bahasa Indonesia menjadi salah satu bahasa internasional. Berikut ini disajikan temuan penelitian dan pembahasan.

\section{Hambatan dari dalam Negeri}

\section{Loyalitas dan kebanggaan terhadap Bahasa Indonesia}

Loyalitas terhadap bahasa Indonesia merupakan keinginan bangsa Indonesia untuk menjaga kemurnian, memelihara kelestarian, dan mempertahankan penggunaan bahasa 


\section{Indonesian Language Education and Literature \\ e-ISSN: 2502-2261 \\ http://www.syekhnurjati.ac.id/jurnal/index.php/jeill/ \\ Vol. 4, No. 1, Desember 2018, 52 - 61}

Indonesia serta berusaha mencegah bahasa Indonesia dari pengaruh dan interferensi dari bahasa lain. Berdasarkan hasil angket yang peneliti kumpulkan dari dosen dan mahasiswa, diketahui bahwa loyalitas mereka terhadap bahasa Indonesia tergolong rendah. Ketika diberi pertanyaan dalam berkomunikasi, bagi saya, yang penting mitra tutur saya memahami yang saya sampaikan, responden rata-rata menjawab "setuju". Namun ketika ditanya apakah Anda berbahasa Indonesia dengan baik dan benar, responden menjawab "kadang-kadang". Ada jawaban yang cukup mengejutkan, yakni ketika menjawab "Sebagai orang Indonesia saya mengikuti perkembangan bahasa Indonesia, kaidah, kosakata, dan bahasa serapan", responden rata-rata menjawab "tidak pernah".

Kebanggaan berbahasa Indonesia merupakan perasaan bangga terhadap bahasa Indonesia yang memiliki kekhasan yang tidak dimiliki oleh bahasa lain. Kekhasan tersebut termasuk kelebihan-kelebihan yang dimiliki bahasa Indonesia dibanding bahasa lain. Peneliti merasa senang dengan hasil jawaban angket yang telah terkumpul. Ketika responden diberi pertanyaan tentang penggunaan bahasa asing dalam dunia akademis, spanduk kegiatan, papan nama, dan acara televisi yang menggunakan bahasa asing, responden rata-rata menjawab "tidak setuju". Meskipun demikian, dalam kenyataannya, penggunaan bahasa asing dalam berbagai hal di atas tetap marak.

Agar bahasa Indonesia dapat bertahan dan tidak tergeser oleh bahasa lain, apalagi punah karena tidak lagi digunakan, bangsa Indonesia perlu memiliki loyalitas dan kebanggan terhadap bahasa sendiri. Loyalitas terhadap bahasa merupakan keinginan suatu pendukung bahasa untuk menjaga kemurnian, memelihara kelestarian, dan mempertahankan penggunaan suatu bahasa, bahkan mencegah bahasa tersebut dari pengaruh dan interferensi dari bahasa lain. Fenomena penggunaan bahasa Indonesia yang tidak benar harus sedikit demi sedikit dihindari sembari ditanamkan rasa cinta dan setia terhadap penggunaan bahasa Indonesia. Kesetiaan terhadap bahasa Indonesia merupakan pengamalan Sumpah Pemuda butir ketiga, yakni "Menjunjung bahasa persatuan Bahasa Indonesia".

Kesetiaan terhadap bahasa Indonesia haruslah dilengkapi dengan kebanggaan terhadap bahasa Indonesia. Kebanggaan berbahasa Indonesia merupakan perasaan bangga terhadap bahasa sendiri yang memiliki kekhasan yang tidak dimiliki oleh bahasa lain. Menggali kekhasan bahasa Indonesia merupakan salah satu cara untuk membangkitkan rasa bangga terhadap bahasa Indonesia (Wijana dan Rohmadi, 2013). 
Selain itu, kelestarian bahasa juga bergantung pada sikap terhadap bahasa Indonesia. Mulyaningsih (2017) dalam penelitiannya terhadap mahasiswa di 38 PerguruanTinggi di Cirebon menyimpulkan bahwa sikap mahasiswa terhadap bahasa Indonesia adalah baik. Mahasiswa bangga menggunakan bahasa Indonesia meskipun telah mempelajari bahasa asing. Ada tiga faktor yang membuat mahasiswa bersikap baik dan bangga berbahasa Indonesia. Pertama, mahasiswa menyadari bahwa bahasa Indonesia memiliki peran penting dalam dunia pendidikan. Kedua, mahasiswa lebih percaya diri jika berbicara dengan menggunakan bahasa Indonesia. Ketiga, mahasiswa yakin bahwa bahasa Indonesia akan tetap eksis karena banyaknya jumlah penutur.

Di atas sudah dijelaskan bahwa kebanggaan terhadap bahasa sendiri merupakan kunci bertahannya sebuah bahasa lokal. Kebanggaan terhadap bahasa sendiri dapat dilihat dari frekuensi penggunaan bahasa tersebut dibanding penggunaan bahasa lain. Kondisi seperti ini oleh Fishman (1972) disebut sebagai loyalitas bahasa. Sumarsono (1990; 2014) dalam penelitiannya terhadap bahasa Melayu Loloan yang masih lestari digunakan oleh masyarakat Loloan di Bali sejak abad ke 18, menyebut lima faktor penting yang membuat sebuah bahasa mampu bertahan. Lima faktor penting tersebut adalah (1) wilayah permukiman yang terkonsentrasi, (2) adanya toleransi dari masyarakat mayoritas, (3) adanya sikap tidak akomodatif terhadap budaya lain, (4) adanya loyalitas terhadap bahasa, dan (5) adanya kesinambungan dari generasi ke generasi.

\section{Fenomena Bahasa Indonesia jaman "Now"}

Menarik sekali acara memperingati Sumpah Pemuda di Istana Bogor, 28 Oktober 2017. Acara tersebut ditayangkan langsung di televisi swasta nasional dengan tajuk "Sumpah Pemuda Zaman Now". Istilah "zaman now" yang akhir-akhir ini cukup menggejala di kalangan remaja sangat menarik untuk diteliti. Berdasarkan data yang ada ditemukan beberapa tulisan yang menggunakan istilah tersebut. Selain itu, istilah "Kids jaman now" juga menjadi viral di media sosial. Tidak tanggung-tanggung, seorang pejabat tinggi negeri ini pun terlihat tidak keberatan dengan penggunaan bahasa Indonesia yang tidak benar itu.

\section{Fenomena Indolish}


Telah terjadi juga fenomena penggunaan bahasa Indonesia yang dicampur bahasa Inggris yang atau biasa disebut Indolish. Fenomena Indolish oleh para pejabat Indonesia merupakan indikasi dari rendahnya kebanggaan terhadap bahasa Indonesia. Hasil angket menunjukkan bahwa motivasi penggunaan Indolish adalah karena adanya anggapan bahwa bahasa tersebut lebih bergengsi, lebih ilmiah, dan lebih membanggakan daripada bahasa Indonesia.

Dalam sebuah penelitian kecil-kecilan yang dilakukan oleh Wieke Gur (2009) ditemukan fenomena yang cukup menarik untuk diperhatikan, yakni munculnya fenomena Indolish atau penggunaan bahasa Indonesia yang dicampur dengan bahasa Inggris. Penelitian tersebut mengamati penggunaan bahasa Indonesia para pejabat tinggi negara. Dalam sekali wawancara, seorang pejabat bisa menggunakan bahasa asing lebih dari $40 \%$. Mengutip Sneddon, Wieke Gur (Kompas, 24 November 2009) memberi contoh sebuah wawancara seorang tokoh sebagai berikut. "Gus Dur memerlukan 'transisional period', saya kira 'something like three years or so' untuk itu, ... MPR yang anggota-anggotanya sangat 'selfish', sangat 'group oriented', dan berpikir tentang 'short term projects'." Tentu banyak contoh-contoh lain yang tidak perlu dikemukakan di sini. Temuan tersebut tentu saja memalukan sekaligus memilukan. Pasalnya, seorang pejabat negara yang mestinya memberi contoh penggunaan bahasa Indonesia yang baik dan benar sebagai indikator nasionalisme, justru memberi teladan penggunaan bahasa Indonesia yang tidak baik.

Terdapat dua kubu terkait keberadaan indolish. Ada yang setuju dan ada yang tidak setuju. Kelompok yang setuju mengatakan bahwa menyisipkan kosakata asing ke dalam wacana lisan formal tidak perlu dirisaukan karena bahasa Indonesia masih kekurangan kosakata yang mampu menjelaskan konsep yang dimaksud dalam wawancara tersebut. Lagi pula, bahasa Inggris merupakan bahasa komunikasi internasional sehingga sudah selayaknya semua orang belajar bahasa Inggris. Kelompok yang tidak setuju mengatakan bahwa penggunaan kosakata bahasa asing dalam berbahasa Indonesia dalam wacana formal menunjukkan bahwa pelan-pelan bahasa Inggris telah menggeser posisi bahasa Indonesia sebagai bahasa nasional.

Kadarisman (2016) melihat dari sisi pembelajaran bahasa Inggris. Menurutnya, maraknya penggunaan bahasa Inggris di negara-negara non-Inggris telah menyebabkan munculnya bahasa Inggris baru yang dikenal dengan “World Englishes”seperti Indoglish (Indonesian-English), Singlish (Singaporean English), Taglish (Tagalog English), 
Chinglish (Chinese English), Konglish (Korean English), Runglish (Russian English), Thanglish (Thai English), dan lainnya. Hal wajar jika orang-orang non-Inggris berbahasa Inggris dengan sistem fonologi dan sintaksis bahasa ibunya karena orang-orang tersebut hampir tidak mungkin mampu berbahasa Inggris sama persis dengan penutur sejatinya (native speaker).

\section{Harapan dari Luar Negeri}

\section{Meningkatnya Jumlah Lembaga BIPA}

Seiring dengan posisi strategis Indonesia dalam percaturan dunia, bahasa Indonesia semakin mendapatkan perhatian dunia. Kini, bahasa Indonesia dipelajari di beberapa perguruan tinggi di luar negeri. Di Amerika Serikat, bahasa Indonesia dipelajari di 13 universitas. Di Australia, tidak kurang dari 30 mengajarkan bahasa Indonesia. Bahkan sejak SD sampai SMA bahasa Indonesia menjadi salah satu mata pelajaran wajib. Bahasa Indonesia juga dipelajari di beberapa universitas di Thailand, Korena Selatan, Vietnam, Jepang, Italia, Jerman, dan Mesir. Dari tahun ke tahun, layanan Bahasa Indonesia bagi Penutur Asing (BIPA) selalu meningkat. Saat ini, setidaknya ada 76 lembaga pelayan BIPA di Indonesia, dan 179 lembaga BIPA di luar negeri.

\section{Internasionalisasi Bahasa Indonesia}

Indonesia kini semakin diperhitungkan oleh dunia karena memiliki posisi strategis dari berbagai aspek, baik geografis, demografis, ekonomi, politik, sosial, budaya, dan agama (Sammeng, 1995). Dari aspek geografis, Indonesia terletak di antara dua benua dan dua samudra. Dari aspek demografis, Indonesia memiliki jumlah penduduk terbesar keempat di dunia. Dari aspek ekonomi, jumlah penduduk Indonesia yang banyak menjadi negara yang menguntungkan untuk berinvestasi dan menjadi pasar potensial bagi produkproduk luar negeri. Dari aspek politis, Indonesia menganut politik luar negeri yang bebasaktif yang membuat Indonesia sebagai negara tujuan yang aman untuk dikunjungi. Jumlah etnis dan budaya yang beragam membuat Indonesia sebagai negara kaya budaya. Selain itu, Indonesia juga negara pluralis dengan enam agama namun saling menghargai dan menghormati sehingga Indonesia sering menjadi model toleransi beragama. Beberapa hal di atas menjadi alasan mengapa semakin banyak orang asing mempelajari bahasa Indonesia.

Internasionalisasi bahasa Indonesia juga didukung oleh beberapa hal, seperti: jumlah penutur dan menjamurnya lembaga layanan BIPA, baik di dalam maupun di luar negeri. 
Berdasarkan dua hal ini, Susanto dan Rofiuddin (2016) meyakini bahwa bahasa Indonesia memiliki peluang besar untuk menjadi bahasa resmi ASEAN. Bahkan Wicaksono (2016) melihat maraknya pertumbuhan pengajaran BIPA di berbagai negara semakin memperbesar peluang internasionalisasi bahasa Indonesia. Namun, ada kecurigaan akan kemungkinan munculnya dampak negatif dari menjamurnya layanan BIPA di luar negeri. Boleh jadi, kemampuan berbahasa Indonesia akan digunakan untuk memasuki pasar ekonomi Indonesia sehingga secara ekonomi menguasai Indonesia.

Sujana (2016) melihat maraknya pembelajaran BIPA sebagai peluang bisnis, profesi, kajian, sentra pendidikan, pariwisata, dan kerja sama luar negeri. Maraknya pembelajaran BIPA merupakan peluang besar untuk menjadikannya sebagai bisnis. Lembaga bahasa, pusat bahasa, dan kursus bahasa dapat menambah layanan pembelajaran BIPA. Dengan bertambahnya layanan BIPA, mengajar BIPA dapat berkembang menjadi sebuah profesi baru. Hal ini terbukti dari setiap seminar BIPA, simposium BIPA, dan pelatihan BIPA, selalu diminati. Karena BIPA menjadi sebuah profesi baru, maka BIPA juga menarik minat para pemerhati bahasa untuk mengkaji pembelajaran BIPA dari berbagai aspek. Dengan demikian, pusat bahasa dan lembaga layanan BIPA akan menjadi sentra pendidikan. Meningkatnya permintaan pengajar BIPA membuat BIPA sebagai sentra pendidikan calon pengajar BIPA seperti program lokakarya sebagaimana dilakukan oleh IALF Bali, sertifikasi pengajar BIPA seperti yang dilakukan oleh APBIPA Bali, atau menjadikan BIPA sebagai mata kuliah baru di Jurusan Bahasa.

Selain itu, BIPA juga mendukung pariwisata tanah air. Pasalnya, Indonesia merupakan salah satu destinasi wisata dunia karena keindahan alamnya. Oleh karena itu, dengan mengajar BIPA sekaligus dapat mengenalkan budaya dan pariwisata di Indonesia. Terakhir, BIPA dapat mendukung berlanjutnya kerja sama luar negeri, baik lembaga pemerintah maupun perguruan tinggi. Pembelajar BIPA sebagian besar menjadikan bahasa Indonesia sebagai tujuan antara, bukan tujuan utama. Tujuan utamanya adalah melakukan penelitian di Indonesia, berbisnis dengan orang Indonesia, atau membantu pendidikan di Indonesia. Untuk itu, di beberapa perguruan tinggi dibentuk Lembaga Pelaksana Tugas di bawah wakil rektor seperti Overseas Student Office (OSO), Office of International Affairs (OIA), dan sejenisnya.

Dalam diskusi ringan para dosen bahasa yang tergabung dalam Ikatan Kaprodi Bahasa dan Sastra Indonesia (IKAPROBSI) terdapat kegelisahan tentang menurunnya 

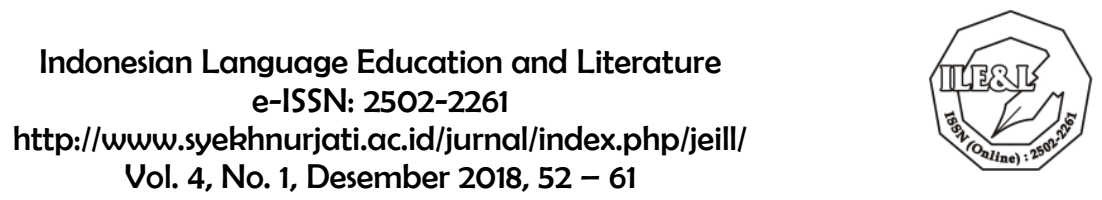

kesetiaan dan kebanggaan berbahasa Indonesia di kalangan pejabat, akademisi, dan di ranah publik. IKAPROBSI mengusulkan beberapa hal, antara lain: (1) kebijakan jurnal yang mengharuskan berbahasa Inggris, perlu ditinjau ulang, (2) kebijakan tenaga kerja asing yang tidak harus bisa berbahasa Indonesia harus dicabut, (3) sekolah internasional yang ada di Indonesia harus menggunakan bahasa Indonesia sebagai bahasa pengantar dalam pengajaran/pendidikan, (4) UKBI (Ujian Kompetensi Berbahasa Indonesia) sebagai salah satu syarat untuk ujian skripsi dan tenaga kerja asing, dan (5) penguasaan bahasa Indonesia sebagai prasyarat bekerja.

\section{SIMPULAN}

Berdasarkan temuan dan pembahasan di atas, dapat ditarik beberapa simpulan. Pertama, bangsa Indonesia memiliki kesetiaan dan kebanggaan yang rendah terhadap bahasa Indonesia. Hal itu terbukti dari hasil angket yang terkumpul dari dosen dan mahasiswa. Kedua, minat orang asing semakin tinggi untuk mempelajari bahasa Indonesia dengan berbagai alasan. Kini bahasa Indonesia dipelajari di 13 universitas di Amerika Serikat, 30 universitas di Australia, beberapa universitas di Thailand, Korea Utara, Vietnam, Jepang, Italia, Jerman, dan Mesir. Sejauh ini, ada 76 lembaga BIPA di Indonesia dan 179 lembaga BIPA di luar negeri. Dengan kata lain, pemartabatan bahasa Indonesia, di satu sisi, mendapatkan hambatan di dalam negeri oleh bangsa Indonesia sendiri, yakni rendahnya kebanggaan dan loyalitas terhadap bahasa Indonesia. Di sisi lain, bangsa lain semakin banyak yang tertarik mempelajari bahasa Indonesia.

\section{DAFTAR PUSTAKA}

Fishman, J. A. (1972). Language and Sociocultural Change. California: Academic Press.

Hasanah, I., dkk. (2015). Fenomena Penggunaan Bahasa Asing dalam Penamaan Bisnis Kuliner di Kawasan Soekarno Hatta Kota Malang. Jurnal Lingkar Widyaswara.

Kadarisman, A. E. (2016). Local Wisdom with Universal Appeal: Dynamic of Indonesian Culture in Asean Context. Seminar Internasional LSCAC. Malang: Universitas Negeri Malang.

Mayuko, H. (2017). Materi dalam Pengajaran Bahasa Indonesia di Universitas di Jepang dan Tindakan Lanjutannya. Makalah disampaikan di Simposium Internasional BIPA di Jogjakarta, 23-14 Agustus 2017.

Miles, M. B. \& Huberman, A. M. (1992). Analisis Data Kualitatif. (terj. Tjejep Rohendi Rohidi). Jakarta: Penerbit Universitas Indonesia. 
Mulyaningsih, I. (2017). Sikap Mahasiswa terhadap Bahasa Indonesia. Indonesian Language Education and Literature, 3(1), $79-87 . \quad$ DOI: http://dx.doi.org/10.24235/ileal.v3i1.1525.

Sammeng, A. M. (1995). Pengajaran Bahasa Indonesia sebagai Bahasa Asing serta Peranannya. Makalah disampaikan dalam Konggres BIPA 1995 Fakultas Sastra Universitas Indonesia.

Sumarsono. (2014). Sosiolinguistik. Yogyakarta: Penerbit SABDA bekerjasama dengan Pustaka Pelajar.

Sujana, I. M. (2012). Program Bahasa Indonesia untuk Penutur Asing (BIPA): Peluang, Tantangan, dan Solusi. Makalah disampaikan pada Seminar Internasional "Menimang Bahasa Membangun Bangsa" di FKIP Universitas Mataram. 5-6 September 2012.

Susanto, G. \& Rofiuddin, A. (2015). Peta Pembelajaran Bahasa Indonesia bagi Penutur Asing dan Peluang Bahasa Indonesia sebagai Bahasa resmi ASEAN. Makalah Seminar Internasional bahasa Nusantara sebagai Pemecah Masalah Globalisasi. Jurusan Bahasa Melayu, Fakulti Sains Kemanusiaan dan Sosial, Universiti Rajabath. Yala: Thailand.

Sumarsono. (2014). Sosiolinguistik. Yogyakarta: Penerbit SABDA bekerja sama dengan Pustaka Pelajar.

Suyitno, I. (2007). Pengembangan Bahan Ajar Bahasa Indonesia untuk Penutur Asing (BIPA) berdasarkan Hasil Analisis Kebutuhan Belajar. Wacana, Journal of the Humanities of Indonesia, 9 (1), 62. https://doi.org/10.17510/wjhi.v9i1.223

Tuan, N. T. (2017). Pengajaran Bahasa Indonesia dan Permasalahan terhadap Bahan Ajar di Vietnam. Makalah disampaikan di Simposium Internasional BIPA di Jogjakarta, 23-14 Agustus 2017.

Wijana, P. \& Rohmadi, M. (2013). Sosiolinguistik; Kajian Teori dan Analisis. Yogyakarta: Pustaka Pelajar.

Wicaksono, A. (2016). Tantangan BIPA pada Era MEA. Gagasan, Solo Pos, 15 Maret 2016 diakses di http://www.iain-surakarta.ac.id.

Wieke, G. (2009). Bahasa Indolish. Kompas, 24 November 2009 diakses di https://rubrikbahasa.wordpress.com/2009/11/24/bahasa-indolish/ 